\title{
MULTICRITERIAL SEARCH FOR RATIONAL SOLUTIONS WHEN DEVELOPING BUILDING COMPOSITES
}

\author{
${ }^{1}$ Lyashenko T.V., D.Sc., Professor, \\ frabul16@gmail.com, ORCID: 0000-0002-6232-4866 \\ ${ }^{1}$ Antoniuk N.R., Ph.D., Associate Professor, \\ antonuk_nr@ukr.net, ORCID: 0000-0003-1730-0723 \\ ${ }^{1}$ Odessa State Academy of Civil Engineering and Architecture \\ 4, Didrichson street, Odessa, 65029, Ukraine
}

\begin{abstract}
The multicriteriality of the tasks when developing high performance building composites and the need for a quantitative description of the relations of materials characteristics, quality criteria and resource savings, etc. with factors of material composition, production process and operating conditions are emphasized. The approaches commonly used to solve multicriterial optimization problems and their disadvantages are called. The proposed method of iterative random scanning the fields of material properties in coordinates of composition and process parameters is described, allowing the variety of optimization problems to be solved. Designed to find the compromise solutions, by several criteria of optimality with requirements for a number of constraints criteria, the method also allows the acceptable and optimal solutions by individual criteria to be determined. The number of optimality criteria (which must be minimized, maximized, or improved compromisedly) and of constraints criteria (the specified ranges of their values should not be violated) is not limited. The algorithm is quite universal. It is easily implemented in a table processor, in an interactive mode. At any iteration, resource-intensive factors requiring minimization can be added to the number of the criteria, other conditions of the problem can be changed (with new technological information being obtained in computational experiment). The stages and results of the search for a compromise optimum are illustrated by the example of developing the composition of filled carbamide binder.
\end{abstract}

Keywords: compromise optimization, composite material, experimental-statistical model, composition-process field, iterative random scanning, filled carbamide binder.

Introduction. When developing high performance building materials, one has to take into account a lot of criteria (properties, $Y$ ). These may be technological and structural characteristics (viscosity, workability, porosity), physical and mechanical properties (density, heat conductivity, strength, elasticity modulus), durability indices (water and frost resistance, in particular), resource saving and other environmental criteria. Coefficients of fundamental and conceptual equations related to designing the material and the estimates got on simulated structures could be also among the criteria.

It is quite obvious that the desired structure and the desired properties of the material can only be obtained through certain multicomponent compositions, at certain process parameters (CPfactors, including those of operational conditions). The values of these variables, that should be set, present the vector of CP-factors, $\boldsymbol{x}=\left(x_{1}, \ldots, x_{\mathrm{k}}\right)$, which can be varied in certain domain $\Omega_{\mathrm{x}}$.

To determine (to find) the values of $x$ that would provide the desirable properties of the materials at various stages of their life (mix, forming structures, hardened composite) one needs the quantitative descriptions of the relations of the criteria $Y$ with factors vector $\boldsymbol{x}$. ExperimentalStatistical models (ES-models, [1-3]), describing the fields of material properties in CP-coordinates $[3,4]$, are the ones that can connect directly the properties with CP-factors. In building materials science, in most cases, a second-order polynomial (1) is used as a type of EC-model (in some cases including effects up to $4^{\text {th }}$ order), with normalized $\left|x_{\mathrm{i}}\right| \leq 1$ and coefficients $b$ expressing individual and synergistic effects of composition components and process parameters.

$$
Y(x)=b_{0}+\sum_{i} b_{i} x_{i}+\sum_{i} b_{i i} x_{i}^{2}+\sum_{i<j} b_{i j} x_{i} x_{j}
$$


Some of the properties $\left(Y_{\Omega}\right)$ must comply with specified requirements (set by a customer or some standard, or by an idea of researcher), which may cut out a restricted region of acceptable $\mathrm{CP}$-solutions $(\Omega)$ from the whole $\Omega_{\mathrm{x}}$. The levels of other criteria $\left(Y_{\mathrm{O}}\right)$ should be minimized or maximized (optimized).

When optimization problem is formulated it is commonly the task with only one optimality criterion $Y_{\mathrm{O}}$. This could be one of the properties or CP-factor (specifically, minimized should be the dosage of some expensive component or the process parameter that lengthens the time of obtaining certified material). The task is formulated as a problem of conditional optimization (of linear or non-linear programming), with a specific "main" criterion as an objective function and all other $Y$ as constraints. As the only optimality criterion the integral criterion, with weighting multipliers, may also be applied, such as desirability function $[5,6]$. The latter is widely used in engineering design when several, often conflicting, criteria are important, and multiobjective optimization problem is formulated.

There are a great many publications (in particular, [7] and those mentioned in $[8,9]$ ) on the methods to find the optimal engineering solutions, including those used when developing building composites [10]. The analytical method of determining the acceptable and optimal solutions by the $2^{\text {nd }}$ order models (1), described in [11], should be also mentioned, as well as graphic-analytical approach $[1,2,12]$, which helped to solve a lot of specific tasks.

It must be recognized, however, that the most commonly used approach for multi-objective problem is to assign weights for every criterion, and the most popular method is the use of desirability function [13-16]. But the need to assign weights to particular criteria is the main disadvantage of the method. The "stiffness" of the decision, the inability to change flexibly the priorities in the process of the search is also a significant drawback.

The alternative is the search for the compromise (Pareto optimal solution [7, 9, 17]), which could be performed without any preference information. Potential optimal solutions would not then "get lost due to enforced weighting of the multiple objective functions" [18]. It is also important to arrange an interactive iterative search process, and the authors of [19] support this concept. As they justly write, the decision maker (DM), "who is supposed to have insight into the problem and be able to specify preference information related to the objectives considered and different solution alternatives", "can specify and correct her/his preferences and selections progressively" during the search process "until the DM has found the most preferred solution (or some stopping criterion is satisfied)".

The aim of this paper is to promote the application of the method, which allows solving the inexhaustible diversity of multicriterial optimization problems that could arise in the study and design of multicomponent materials.

The method is easily implemented in a table processor, in an interactive mode. The number of optimality criteria $Y_{\mathrm{O}}$ (which must be minimized, maximized, or improved compromisedly) and constrain criteria $Y_{\Omega}$ (the specified ranges of their values should not be violated) is not limited in principle.

The idea of the method of iterative random scanning the composition and process fields $(\mathrm{CP}-$ fields) appeared quite a few years ago. Its realization has undergone a number of modifications for solving various optimization tasks when studying and designing the composites of various purpose, on silicate and polymer matrices, with various fillers, additives, fibre and so on. The solutions obtained were described in a number of papers [20 et al] and in the book [3], with some details of the method. But it was not presented sufficiently. Below the method is described in general form, the specific task being used to demonstrate the search process.

General statement of the problem. The variety of the tasks to be solved can be symbolically represented in the form (2):

$$
Y_{\mathrm{Oi}}(\boldsymbol{x}),\left(i=1, \ldots, M_{\mathrm{O}}\right) \rightarrow \min (\max ), \boldsymbol{x} \in \Omega:\left\{Y_{\Omega \mathrm{j}}(\boldsymbol{x}) \leq(\geq) Y_{\Omega \mathrm{j} . \mathrm{spec}}\left(j=1, \ldots, M_{\Omega}\right)\right\}
$$

The symbolic notation (2) covers, in particular, the problem with the single optimality criterion (individual or integral) and the problem of determining just the set of acceptable CPvariants (when $M_{\mathrm{O}}=0$ ), that fall into the region of acceptable solutions, $\Omega \subseteq \Omega_{\mathrm{x}}$, defined by direct and functional constraints (boundaries $x_{\mathrm{i}}= \pm 1$ and $Y_{\Omega \mathrm{j}}(\boldsymbol{x})=Y_{\Omega \mathrm{j} . \mathrm{spec}}, 2$ regions coincide if $M_{\Omega}=0$ ).

100 Bulletin of Odessa State Academy of Civil Engineering and Architecture, 2020, no. 79, page 99-108 
In the general case, expression (2) formulates the problem of multicriterial compromise optimization in a multidimensional bounded domain. To solve just such problems the described method of multifactor search for a compromise optimum is most of all intended.

The strategic provisions on which the search procedure is based are as follows.

1. Generation of in principle unlimited number of points $\boldsymbol{x}$ in the domain $\Omega_{\mathrm{x}}$ of the criteria $Y(\boldsymbol{x})$ - in the multifactor region of the multicriterial field. In this way any number of possible CP-options is simulated.

2. Estimating the field level of any criterion from in principle unlimited set of material quality, cost, or resource saving criteria for each variant $\boldsymbol{x}$ by experimental-statistical or other model, taking into account the risk of modelling. This is how responses are simulated in the computational experiment.

Provisions 1 and 2 provide the ability to perform both deterministic and random scanning of CP-fields.

3. Selecting for comparison (and further choosing the "best") from those CP-variants that satisfy the requirements by $Y_{\Omega}$ criteria.

Position 3 ensures the formation of the region of acceptable solutions $\Omega$.

4. Implementation of the search principles:

- it is an iterative process carried out from a certain initial approximation, the initial search region,

- at each iteration, actions are taken that lead to a reduction of the search area, to a narrowing of the uncertainty intervals for factors $x$.

5. Dialogue of a material scientist (decision maker) with a computer at each iteration. You can change the priorities of the criteria, the search ranges, the "speed" of maximization and minimization of one or another $Y_{\mathrm{O}}$ due to the factors (from technical and economic positions and depending on the results of previous iterations), adapt search parameters to changes in the task conditions. A flexible sequential strategy of computational experiment is carried out.

On these positions a procedure of iterative random scanning of the CP-fields $Y(\boldsymbol{x})$ is built that allows solving problems (2). The procedure can be better demonstrated in the case of only three material composition variables. That is why used below are the data obtained when developing the carbamide binder filled with mixture of andesite and silicon carbide grains (abrasive production waste) $[3,4]$ and the specific statement of the multicriteria optimization problem [3].

Experiment, models, and optimization problem when developing carbamide composite (illustrative case). Three formulation factors (Table 1) were varied in the designed experiment. The obtained data on the properties of 15 compositions [3], according to experiment design of the $2^{\text {nd }}$ order (15 points $\boldsymbol{x}$ in factors cubic region, Fig. 1), allowed ES-models of kind (1) to be built, in particular, for effective viscosity of the mix $(\eta, \mathrm{Pa} \cdot \mathrm{s})$, compression strength $R(\mathrm{MPa})$, elasticity

Table 1 - Values of varied dosages of the components

\begin{tabular}{|c|c|c|c|c|}
\hline \multirow{2}{*}{$i$} & \multirow{2}{*}{ Composition factors } & \multicolumn{3}{|c|}{ Values } \\
\hline & & $x_{\mathrm{i}}=-1$ & $x_{\mathrm{i}}=0$ & $x_{\mathrm{i}}=+1$ \\
\hline 1 & $\begin{array}{l}\text { Filler-polymer mass ratio (degree of filling } F \text { ) } \\
\text { considered as both structure formative and economical factor } \\
\text { that should be maximised to reduce polymer content }\end{array}$ & 2 & 2.25 & 2.5 \\
\hline 2 & $\begin{array}{l}\text { Mass part of silicon carbide (abrasive production waste, specific } \\
\text { surface } 320 \pm 10 \mathrm{~m}^{2} / \mathrm{kg} \text { ) in fine fraction of the filler }(S C \%)\end{array}$ & 0 & 30 & 60 \\
\hline 3 & $\begin{array}{l}\text { Mass part of andesite coarse grains (specific surface } \\
70 \pm 5 \mathrm{~m}^{2} / \mathrm{kg} \text { ) in total amount of the filler }(C A \%)\end{array}$ & 20 & 40 & 60 \\
\hline
\end{tabular}


modulus $E(\mathrm{GPa})$, abrasion resistance $A(\mathrm{~h} / \mathrm{g})$, and water resistance coefficient $K_{\mathrm{W}}$. The coefficients of the models describing the fields of these properties in composition coordinates are shown in Table 2, insignificant effects $( \pm 0$, at $10 \%$ risk and the corresponding experimental errors) are removed. Shown in the same table are the minimal and maximal property levels (estimated with the models). As can be seen, the values of the factors that would provide the optimal levels of individual criteria do not coincide.

Through composition factors $\left(F \sim x_{1}, S C \sim x_{2}, C A \sim x_{3}\right)$, it is necessary to provide the highest possible levels of elasticity modulus $E$
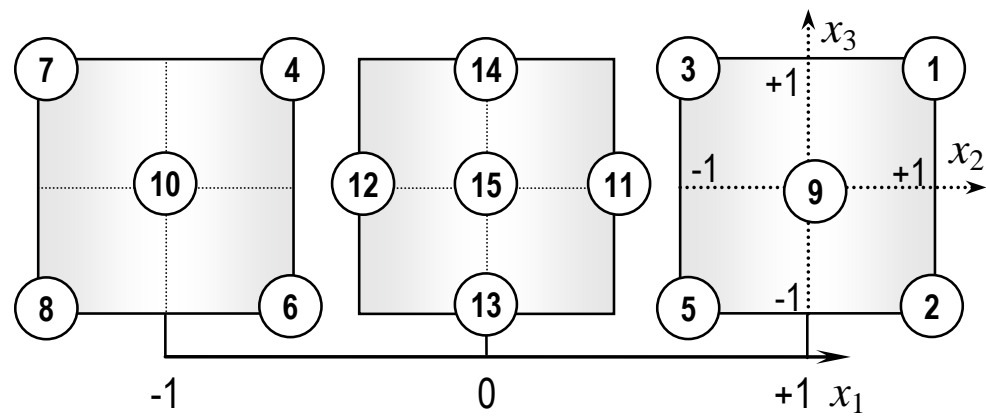

Fig.1. Points of the experiment design $(\mathrm{GPa})$ and water resistance coefficient $K_{\mathrm{W}}$, when meeting the requirements: for the viscosity of the mix, $30 \leq \eta \leq 60 \mathrm{~Pa} \cdot \mathrm{s}$, for compression strength, $R \geq 70 \mathrm{MPa}$, and abrasion resistance, $A \geq 6 \mathrm{~h} / \mathrm{g}$. Thus, the compromise optimisation problem (3) has been formulated.

$$
E(\boldsymbol{x}) \rightarrow \max , K_{\mathrm{W}}(\boldsymbol{x}) \rightarrow \max , \boldsymbol{x} \in \Omega:\{30 \leq \eta(\boldsymbol{x}) \leq 60, R(\boldsymbol{x}) \geq 70, A(\boldsymbol{x}) \geq 6\}
$$

\section{Procedure of iterative random scanning CP-fields to find compromise optima.}

1. Each iteration (with number $\boldsymbol{s}$ ) consists of two stages. At the $1^{\text {st }}$ stage $(\boldsymbol{s} / \mathbf{1})$ in the search domain $\Omega_{\mathrm{s}} N$ uniformly distributed random CP-variants are generated, defined by $k$ normalized variables $x_{\mathrm{i}}$.

In the typical case under consideration $\Omega_{\mathrm{s}}$ is a $k$-dimensional rectangular prism bounded by the lower and upper possible values of the normalized factors, $x_{\text {i.min }}{ }^{(\mathrm{s})}$ and $x_{\text {i.max }}{ }^{(\mathrm{s})}$.

Table 2 - Coefficients of ES-models for 5 properties of carbamide binder, their minimal and maximal levels, with corresponding coordinates

\begin{tabular}{|c|c|c|c|c|c|}
\hline & $\ln \eta$ & $R, \mathrm{MPa}$ & $E, \mathrm{GPa}$ & $A, \mathrm{~h} / \mathrm{g}$ & $K_{\mathrm{W}}$ \\
\hline$b_{0}$ & 3.27 & 75.3 & 7.97 & 6.69 & 0.880 \\
\hline$b_{1}$ & 0.61 & \pm 0 & 0.36 & 0.22 & -0.011 \\
\hline$b_{2}$ & 0.36 & 9.4 & 1.06 & 1.45 & 0.029 \\
\hline$b_{3}$ & -0.36 & -11.0 & -0.64 & \pm 0 & 0.033 \\
\hline$b_{11}$ & 0.33 & -1.7 & -0.91 & -0.47 & \pm 0 \\
\hline$b_{22}$ & 0.36 & -4.7 & -0.41 & \pm 0 & -0.011 \\
\hline$b_{33}$ & 0.46 & -4.8 & \pm 0 & -1.12 & \pm 0 \\
\hline$b_{12}$ & 0.09 & -1.1 & 0.89 & -0.52 & \pm 0 \\
\hline$b_{13}$ & -0.16 & 2.4 & \pm 0 & +0.85 & 0.024 \\
\hline$b_{23}$ & -0.14 & 4.6 & \pm 0 & \pm 0 & \pm 0 \\
\hline$Y_{\min }$ & $\begin{array}{c}\eta_{\min }=18.5 \mathrm{~Pa} \cdot \mathrm{s} \\
\text { at } x_{1}=-0.83, \\
x_{2}=-0.36, x_{3}=0.19\end{array}$ & $\begin{array}{c}35.6 \\
\text { at } \begin{array}{c}x_{1}=x_{2}=-1, \\
x_{3}=+1\end{array}\end{array}$ & 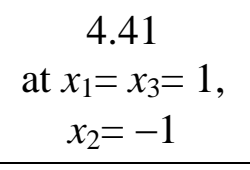 & 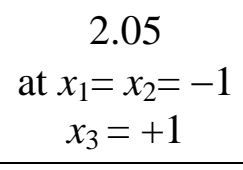 & $\begin{array}{c}0.772 \\
\text { at } x_{1}=+1, \\
x_{2}=x_{3}=-1\end{array}$ \\
\hline$Y_{\max }$ & $\begin{array}{c}\eta_{\max }=464 \mathrm{~Pa} \cdot \mathrm{s} \\
\text { at } x_{1}=x_{2}=+1, \\
x_{3}=-1\end{array}$ & $\begin{array}{c}84.1 \\
\text { at } x_{1}=-0.93, \\
x_{2}=0.62, x_{3}=-1\end{array}$ & $\begin{array}{c}9.68 \\
\text { at } x_{1}=0.68, \\
x_{2}=1, x_{3}=-1\end{array}$ & $\begin{array}{c}9.68 \\
\text { at } x_{1}=0.68, \\
x_{2}=1, x_{3}=-1\end{array}$ & 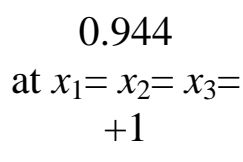 \\
\hline
\end{tabular}


The distribution of $x_{\mathrm{i}}$ within the range of possible values $\left(R P V_{\mathrm{s}}\left\{x_{\mathrm{i}}\right\}\right)$ can be continuous or discrete. The latter is used when the factor values are conditioned by specific possibilities of their regulation.

At the initial iteration ( $s=1$ ), the search region $\Omega_{1}$ is the entire factor area under study, $\Omega_{\mathrm{x}}$ (of CP-fields of the specified constrain criteria and optimality criteria, described by the ES-models). In the typical case $\Omega_{\mathrm{x}}$ is $k$-dimensional cube. So this is like thrown on the factor region (with the range of each $x$ from -1 up to $+1, \Delta x_{i}=2$ ) is multidimensional net, with average coordinate step between the knots (points) equal $\Delta x_{\mathrm{i}} / N^{(1 / \mathrm{k})}$ (for continuous distributions); this is $2 / 8000^{1 / 3}=0.1$ when solving illustrative task (3).

2. By the models, the values of all $Y\left(Y_{\mathrm{O}}\right.$ and $\left.Y_{\Omega}\right)$ at $N$ random points inside the hyperprism are calculated. At the initial iteration the levels of $Y$ are calculated at $N$ points inside the $k$-dimensional cube and at the base (initial) $N_{0}$ points, $2^{\mathrm{k}}$ vertices of the cube (the potential points of extrema that cannot be generated [3]). For subsequent iterations, the initial points are $N_{\mathrm{s}-1}$ "successful" variants found at the previous iteration. In this way, the matrix of the results of computational experiment (MRCE), of size $\left(N+N_{\mathrm{s}-1}\right) \times\left(k+M_{\mathrm{O}}+M_{\Omega}\right)$ is formed and the ranges of possible values for all criteria, $R P V_{\mathrm{s}}\{Y\}$, are determined.

3. Those CP-combinations, which do not meet the normative requirements, are removed from the obtained MRCE (after sorting the rows by $Y_{\Omega}$ ). There are 3 approaches to making this verdict.

"1". The $1^{\text {st }}$ one is to compare with $Y_{\Omega \text {.spec }}$ the model-determinate estimates of $Y_{\Omega}$ (calculated by the model, $[3,4])$. It is this simple approach that has been used to illustrate the algorithm.

"2". Compared with $Y_{\Omega \text {.spec }}$ are the random values of $Y_{\Omega}$, in which added to the estimate determined by the model is its error, that includes normally distributed experimental error $[3,4]$.

"3". The model-determinate estimates of $Y_{\Omega}$ are compared with guaranteeing level $Y_{\Omega \text {.spec. } \alpha \text { (at }}$ certain risk $\alpha$ ) [3]. To assign it, the half-width of the confidence interval is added to the $Y_{\Omega \text { spec }}$ level: with plus sign - if the absence of failures arising from low property levels (strength, durability, etc.) should be guaranteed; with minus sign - when high values of $Y$ are unacceptable (viscosity, thermal conductivity, shrinkage ...).

The remaining $N_{\mathrm{s} / 1} \mathrm{CP}$-variants (after excluding from consideration those not meeting the specification requirements) represent the region of acceptable solutions $\Omega$, the intersection of acceptable regions by each of the constrain criteria. The size of $\Omega$ is defined as the ratio (\%) of the number of acceptable CP-options $\left(N_{\mathrm{s} / 1}\right.$ remaining lines in MRCE) to the number of all $\left(N+N_{\mathrm{s}-1}\right)$ participating in the computational experiment.

This size is slightly different for different methods of excluding the variants. Naturally, when selecting them in the $3^{\text {rd }}$ way, under more stringent restrictions, the areas of acceptable solutions would be smaller. The third method (guaranteed compliance with the standards) would be reasonable with increased reliability requirements. It should be noted that at $\Omega$ below $10 \%$ the CPvariants in this zone may be "unstable" and may turn out to be unacceptable.

The ranges of factor values in $\Omega$ (Range of Acceptable Values, $R A V_{\mathrm{s}}\left\{x_{\mathrm{i}}\right\}$ ) condition, naturally, the ranges of acceptable (feasible) levels of the criteria, $R A V_{\mathrm{s}}\{Y\}$.

4. At the second stage of each iteration $(\mathbf{s} / \mathbf{2})$, the region of the remaining admissible solutions is compressed due to step-by-step bringing its boundaries closer to the individual optima of the optimality criteria one by one, becoming the area of compromise. At each step, those of the acceptable CP-variants are discarded, the values of $Y_{\mathrm{Oi}}\left(i=1, \ldots, M_{\mathrm{O}}\right)$ for which turn out to be worse than the new boundary of $R A V\left\{Y_{\mathrm{Oi}}\right\}$ at this step. Such a boundary may be the median level of the corresponding criterion in its $R A V$ range.

Thus, the ranges of compromise $\left(R C_{\mathrm{s}}\left\{Y_{\mathrm{Oi}}\right\}\right)$ are formed for the optimality criteria and the factors providing them $\left(R C_{\mathrm{s}}\left\{x_{\mathrm{i}}\right\}, \mathrm{i}=1, \ldots, k\right)$, which are narrowed until only a few CP-variants $\left(N_{\mathrm{s}}\right)$ remain in them $\left(N_{\mathrm{s}}\right.$ lines in the MRCE). Then a further reduction in the ranges of compromise, as a rule, loses its meaning, the possibilities of approaching individual extrema of $Y_{\mathrm{O}}$ are exhausted.

Decreased by several orders of magnitude (compared to $N+N_{\mathrm{s}-1}$ ) the number of "successful" variants $\left(N_{\mathrm{s}}\right)$ is basic for the next iteration ( $N$ new ones are added to them, see points 1 and 2 ). 
5. To "compensate" for the possible losses of solutions (in the intervals between random points), the obtained $R C_{\mathrm{s}}\left\{x_{\mathrm{i}}\right\}$ are somewhat expanded (by 0.1-0.2 dimensionless units of normalized factor space from the achieved boundaries, with violation of the requirements for $Y_{\Omega}$ being possible). Thus, a search region is formed for the next iteration $(s+1)$, a new hyperprism with new boundaries of $R P V_{\mathrm{s}+1}\left\{x_{\mathrm{i}}\right\}$. A transition is made to step 1, to the generation of new $N$ points (CPvariants) in the search area reduced in comparison with $\Omega_{\mathrm{s}}$. It could be said that this lessens the size of the cells of multidimensional net thrown on $\Omega_{\mathrm{s}}$, and reduced is the risk of losing the good acceptable variants.

The sufficient number of $\boldsymbol{x}$ generated to scan the property fields depends (in the general case) on the number of factors, rapidly increasing with the dimension of the factor space as it has been shown in [3]. When assigning $N$, the capabilities of the computer should be taken into account, and the iterative procedure allows you to refine the solution at each iteration due to the transition to scanning a smaller part of the field region.

The search process stops when the upper and lower bounds of $R C\left\{Y_{\mathrm{O}}\right\}$ practically close. As a rule, compromise optimal variants can be found in 2-4 iterations. To select the final CP-solution from those remaining in the compromise area, one can use additional criteria or regularization [3], based on the hypothesis of linearity of local property fields in narrowed ranges of compromise: one can average the values of each $x_{\mathrm{i}}$ over the $N_{\mathrm{s}}$ options obtained at the last iteration.

After returning from the normalized to the named variables, the natural values of the factors are rounded to technically feasible.

The search for the best compositions when developing filled carbamide binder. The graphs in Fig. 2 and Fig. 3 display the search for the solutions of the problem (3). The result is:
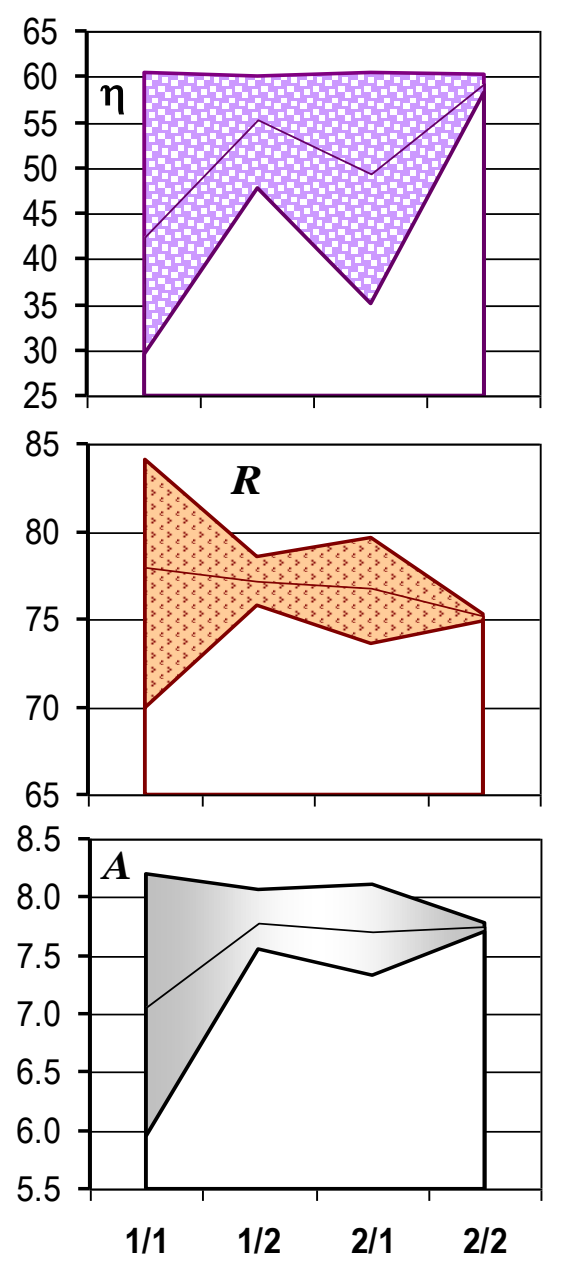
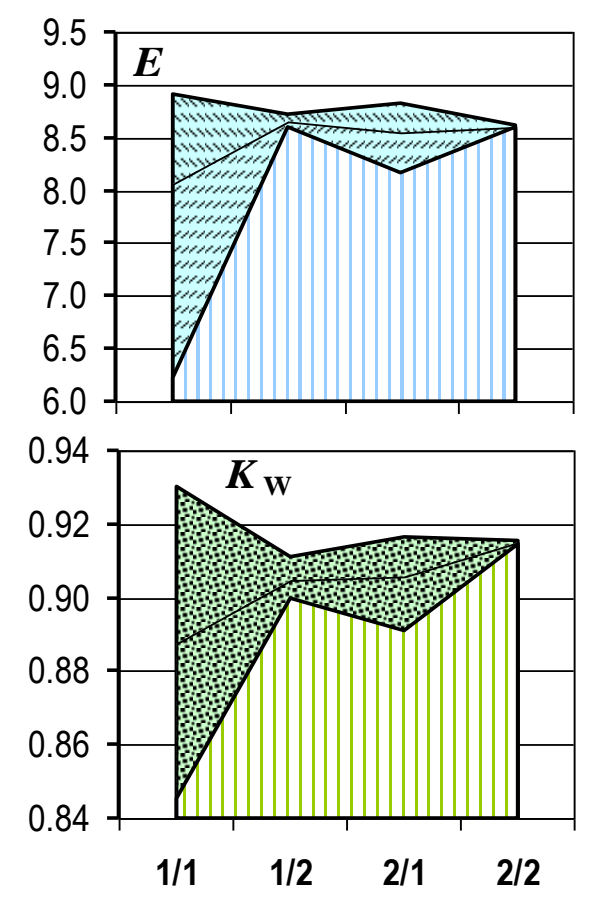

Fig. 2. Ranges of constraints $(\eta, R, A)$ and of optimality criteria ( $E$ and $\left.K_{\mathrm{W}}\right)$ at the stages of the search for compromise optimum 

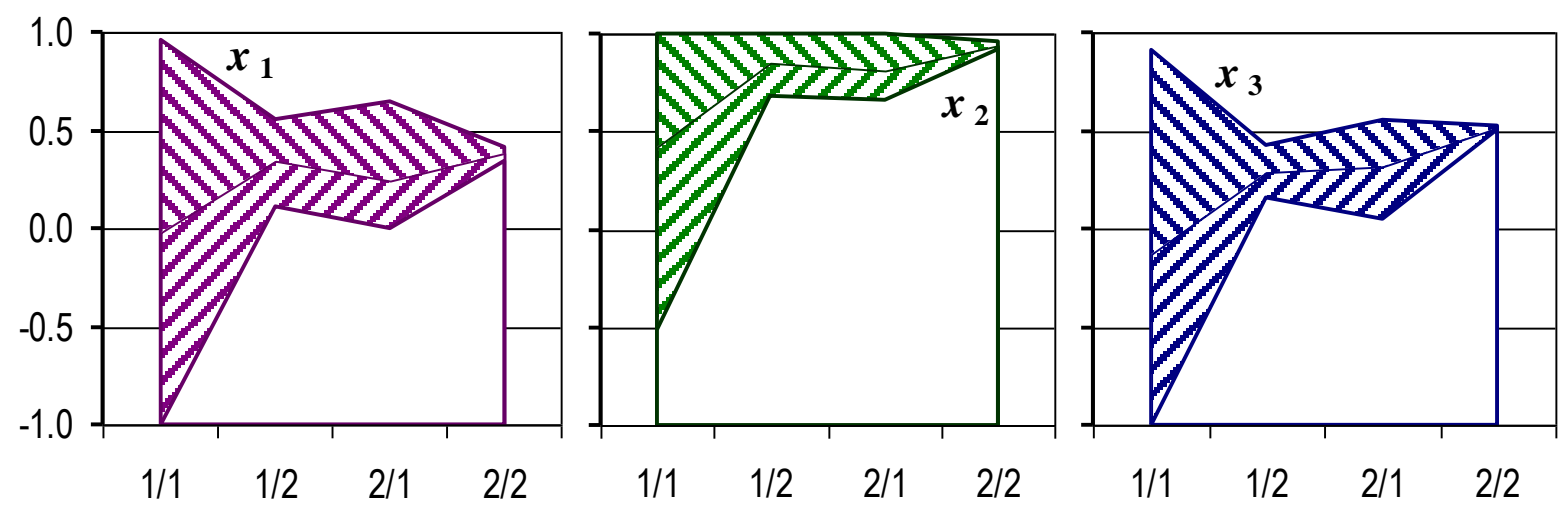

Fig. 3. Ranges of prescription factors

at the stages of the search for compromise compositions

- the degree of filling $F=2.35\left(x_{1}=0.4\right)$,

- the quantity of of silicon carbide in fine fraction of the filler, $S C=58 \%\left(x_{2}=0.93\right)$,

- the quantity of andesite coarse grains in total amount of the filler, $C A=50 \%\left(x_{3}=0.5\right)$.

This composition provides the compromise between the maximum levels of $E$ and $K_{\mathrm{W}}$ (9.7 $\mathrm{GPa}$ and 0.93 ) when meeting the requirements of the other three criteria:

- $E=8.6 \mathrm{GPa}, K_{\mathrm{W}}=0.915$,

- $\eta=59 \mathrm{~Pa} \cdot \mathrm{s}, R=75.2 \mathrm{MPa}, A=7.8 \mathrm{~h} / \mathrm{g}$.

To find these results, $N=8000$ composition variants were generated at each iteration (at its zero stage, $\mathbf{0} / \mathbf{s}$ ), at the first iteration (at stage $0 / 1$ ) added to $N$ were $2^{3}=8$ compositions (vertices of the factor cube). The change in the number of options under consideration $(N \pm)$, from stage to stage, is shown in Fig. 4.

The sufficient number of $\boldsymbol{x}$ generated to scan the property fields depends (in the general case) on the number of factors, rapidly increasing with the dimension of the factor space as it has been shown in [3]. When assigning $N$, the capabilities of the computer should be taken into account, and the iterative procedure allows you to refine the solution at each iteration due to the transition to scanning a smaller part of the field domain.

The ranges of admissible values of the optimality criteria $R A V_{1}\left\{Y_{\mathrm{O}}\right\}$ obtained at stage $1 / 1$ disintegrate into 3 linearly connected ranges (Fig. 5): purposefully expandable range of gain, $R G\left\{Y_{\mathrm{O}}\right\}$, the range of losses, $R L\left\{Y_{\mathrm{O}}\right\}$, and between them "pulsating" and narrowing range of the compromise, $R C\left\{Y_{\mathrm{O}}\right\}$. The values of these ranges with respect to the entire range of acceptable values, $R A V_{1}\left\{Y_{\mathrm{O}}\right\}$, can be used to evaluate the "effectiveness" of the search for a compromise optimum [3].

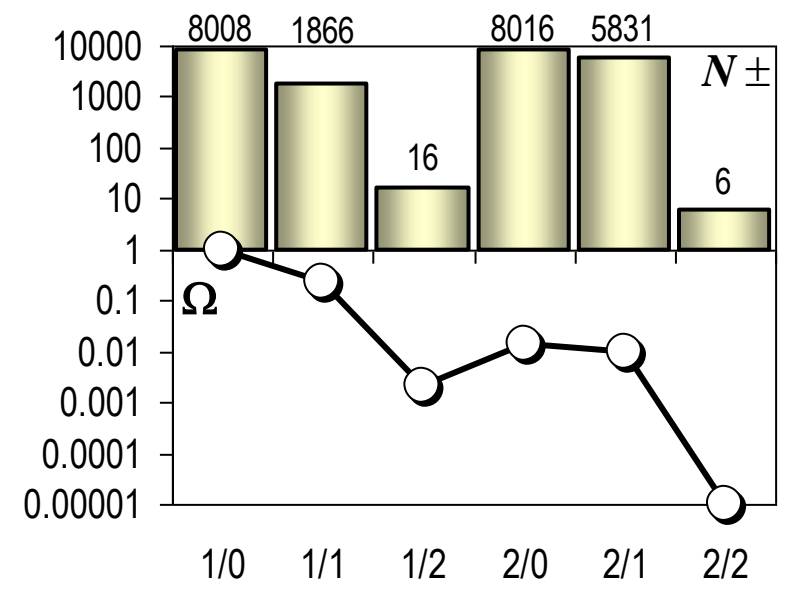

Fig. 4. Changes of the number of competing compositions $N$ and of the relative volume of the search region $\Omega$ in the factor cube along the search process

In a number of tasks (in particular, when ESmodels contain effects of the form $x_{\mathrm{i}}^{2} x_{\mathrm{j}}$, describing the influence of individual factors by parabolas with a variable canonical form) the search may branch out and lead to "enclaves" of solutions [21].

Conclusions. The method of multicriterial optimization described above is quite universal. The algorithm of iterative random scanning the fields of material properties (in general case, characteristics of some system), in coordinates of the controllable factors defining the field levels, enables finding the rational solutions for the great number of multidimensional (multicriterial and 


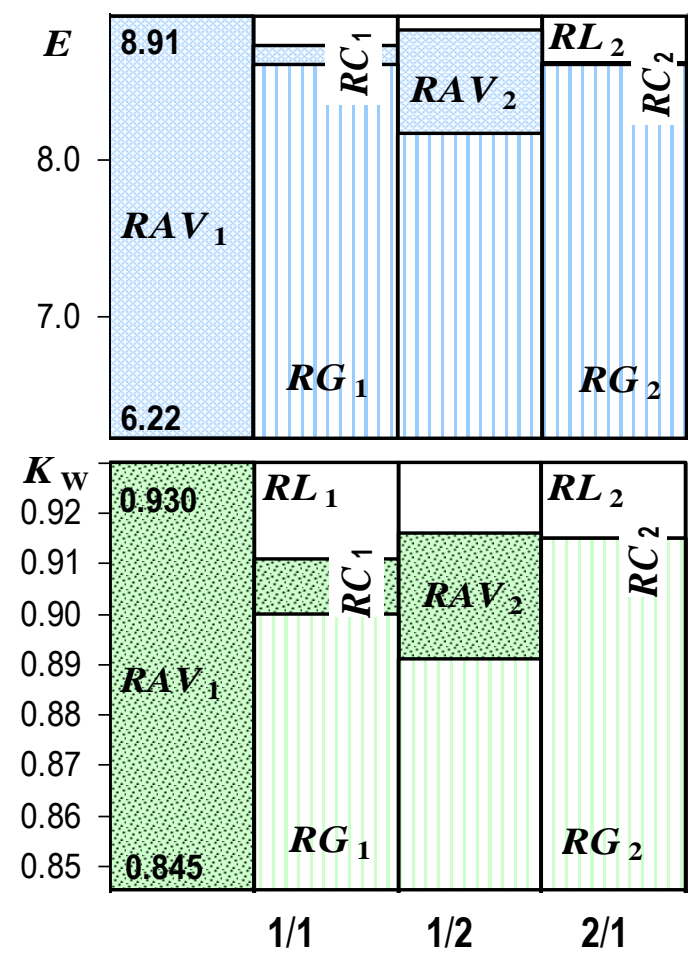

Fig. 5. Ranges of acceptable and compromise values of elasticity modulus $E(\mathrm{GPa})$ and water resistance coefficient $K_{\mathrm{W}}$, of the losses and the gain at the stages of the search for compromise optimum multifactor) problems of optimization. These could be acceptable solutions, just complying with requirements of specifications, the ones providing minimal (maximal) level of some criterion, or the compromise by several criteria.

The algorithm is efficient, has internal logic, and can be recommended for the search of the compromise at large dimension of the factor domain $(k \geq 4)$. The advantages of the method include the lack of the need to create a complex criterion with weight multipliers when solving multicriterial problems and the ability to conduct the search in the dialogue mode.

The property fields are scanned using uniformly distributed random numbers. The numbers can be generated on the continuous or discrete scales. The use of the latter takes into account the possibilities of regulating the factors in production conditions, and both types of the scales can be used for different groups of the factors.

Not only polynomial ES-models can be applied to determine the fields levels, but also the models of some other type and genesis. The algorithm can be implemented using either special software or an available table processor.

\section{References}

[1] V.A. Voznesensky, T.V. Lyashenko, Y.P. Ivanov, I.I. Nikolov, EVM i optimizaciya kompozicionnyh materialov. Budivelnik, Kiev 1989. Available: https://drive.google.com/file/d/0BzKYSjvwhyieS3g0NFd5RjUyOEE/view

[2] T.V. Lyashenko, V.A. Voznesensky, "Experimental-statistical modeling in computational materials science", In: Proc. 3rd Int. Applied Statistics in Industry Conf., Dallas 5-7 June 1995, ACG Press., Wichita, 1995, pp. 287-298. Available: https://drive.google.com/file/d/0BzKYSjvwhyiecDl2enEta0dQc28/view

[3] T.V. Lyashenko, V.A. Voznesensky, Metodologiya recepturno-tehnologicheskih polej v kompyuternom stroitelnom materialovedenii. Astroprint, Odessa 2017. Available: https://drive.google.com/file/d/1FCCYDYRe5jC10N316Wzwf1T4IgladhQF/view

[4] T. Lyashenko, "Composition-process fields methodology for design of composites structure and properties", Int. Symp. Brittle matrix composites 11, Warsaw, Insitute of Fundamental Technological Research PAS, pp. 289-298, 2015.

[5] E.C. Harrington, "The desirable function", Industrial Quality Control, Vol. 21, no. 10, pp. 494-498, 1965.

[6] R.M. Myers, D.C. Montgomery, Response Surface Methodology: Process and Product Optimization Using Designed Experiments, $4^{\text {th }}$ ed., John Wiley \& Sons, 2016.

[7] S.S. Rao, Engineering Optimization. Theory and Practice. $5^{\text {th }}$ ed. John Wiley \& Sons, 2019.

[8] J. Andersson, A Survey of Multiobjective Optimization in Engineering Design. Technical Report: LiTH-IKP-R-1097, 2000.

[9] B. John, "Application of desirability function for optimizing the performance characteristics of carbonitrided bushes", International Journal of Industrial Engineering Computations, 4(3), pp. 305-314, 2013. https://doi.org/10.5267/j.ijiec.2013.04.003.

[10] A.M. Brandt, Optimization Methods for Material Design of Cement-based Composites. Ed. E \& FN Spon, 1998. 
[11] V.A. Voznesensky, Statisticheskie metody planirovaniya eksperimenta v tehnikoekonomicheskih issledovaniyah. 2-e izd. M., Finansy i statistika, 1981.

[12] V.A. Voznesensky et al., Sovremennye metody optimizacii kompozicionnyh materialov. Kiev: Budivelnik, 1983.

[13] T. Lyashenko, V. Voznesensky, K. Qawasmeh, "Experimental-Statistical Modeling and Analysis of Properties of Mortars with Additives", Proc. 13 Ibausil, Weimar, vol. 2, pp. 607-618, 1997.

[14] L. Czarnecki, A. Garbacz, P. Lukowski, J.R. Clifton, Optimization of polymer concrete composites: final report. NIST Report (NISTIR 6361), 1999.

[15] L. Czarnecki, A. Garbacz, J.J. Sokołowska, "Fly Ash Polymer Concretes", In: "Proceeding of the second international conference on sustainable construction materials and technologies-SCMT”, Ancona, 2010, pp. 127-137. Available: http://www.claisse.info/2010\%20papers/p13.pdf.

[16] L. Czarnecki, J.J. Sokołowska, "Optimization of Polymer-Cement Coating Composition Using Material Model", Key Engineering Materials 466, pp. 191-199, 2011. Available: https://doi.org/10.4028/www.scientific.net/kem.466.191.

[17] A. Khalkhali, E. Nikghalb, M. Norouzian, "Multi-objective Optimization of Hybrid Carbon/Glass Fiber Reinforced Epoxy Composite Automotive Drive Shaft", Int. Journal of Engineering (IJE), IJE TRANSACTIONS A: Basics, vol. 28, no. 4, pp. 583-592, 2015. https://doi: 10.5829/idosi.ije.2015.28.04a.13.

[18] B. Fengler, L. Kärger, F. Henning, A. Hrymak, "Multi-Objective Patch Optimization with Integrated Kinematic Draping Simulation for Continuous-Discontinuous FiberReinforced Composite Structures", J. Compos. Sci., vol. 2, pp. 22, 2018. https://doi.org/10.3390/jcs2020022

[19] K. Miettinen, F. Ruiz, A.P. Wierzbicki, "Introduction to multiobjective optimization: interactive approaches", In Multiobjective Optimization, Springer, 2008, pp. 27-57.

[20] T. Lyashenko, A. Gara, I. Podagelis, I. Gailiene, "Epoxy compositions for protecting road structure units in contact with water-oil mixtures", 7th Int. Conf. Environmental Engineering, Vilnius, Technika (Vilnius), vol. 3, pp. 1186-1192, 2008.

[21] N.R. Antoniuk, V.A. Voznesensky, A.D. Dovgan, T.V. Lyashenko, E.V. Martynov, "Penobeton s kompromissnymi urovnyami svojstv - «anklavy» sostavov, obnaruzhivaemye kompyuternym poiskom", Modelirovanie $i$ optimizaciya $v$ materialovedenii. Mat-ly mezhdun. sem. MOK'44, Odessa: Astroprint, 2005, pp. 44-47.

\title{
БАГАТОКРИТЕРІАЛЬНИЙ ПОШУК РАЦІОНАЛЬНИХ РІШЕНЬ ПРИ РОЗРОБЦІ БУДІВЕЛЬНИХ КОМПОЗИТІВ
}

\author{
${ }^{1}$ Ляшенко Т.В., д.т.н., професор, \\ frabul16@gmail.com, ORCID: 0000-0002-6232-4866 \\ ${ }^{1}$ Антонюк Н.P., к.т.н., доцент, \\ antonuk_nr@ukr.net, ORCID: 0000-0003-1730-0723 \\ ${ }^{1}$ Одеська державна академія будівництва та архітектури \\ вул. Дідріхсона, 4, м. Одеса, 65029, Україна
}

\begin{abstract}
Анотація. Констатується багатокритеріальність завдань при розробці високоефективних будівельних композитів і необхідність кількісних описів зв'язків характеристик матеріалу, критеріїв якості, ресурсозбереження та інших критеріїв 3 факторами складу матеріалу, параметрами процесів виробництва i умов експлуатації. Виділяються експериментально-статистичні моделі в якості описів рецептурнотехнологічних полів критеріїв (властивостей). Називаються підходи, які використовуються для вирішення задач багатокритеріальної оптимізації та їх недоліки.

Пропонується метод і описується алгоритм ітераційного випадкового сканування рецептурно-технологічних полів властивостей, який дозволяє вирішувати невичерпне різноманіття оптимізаційних задач. Призначений для пошуку компромісного рішення при декількох критеріях оптимальності і вимогах специфікацій по ряду критеріїв-обмежень, метод дозволяє визначити і безліч допустимих рішень, і оптимуми за індивідуальними
\end{abstract}


критеріями. Алгоритм досить універсальний. Не має принципових обмежень на число критеріїв, що оптимізуються. Легко реалізується в табличному процесорі, в інтерактивному режимі. На будь-якій ітерації до числа критеріїв можуть бути додані ресурсомісткі фактори, що вимагають мінімізації, змінені інші умови задачі (по мірі отримання технологічної інформації в обчислювальному експерименті). На кожній ітерації з множини генерованих рецептурно-технологічних варіантів відбираються ті, що задовольняють нормативним обмеженням, потім область пошуку стискається при покроковому наближенні до оптимумів критеріїв оптимальності. Етапи і результати пошуку компромісного оптимуму ілюструються на прикладі розробки карбамідного зв'язуючого, наповненого сумішшю зерен карбіду кремнію, дрібних і великих зерен андезиту. Визначено склад, що забезпечує компроміс між максимальними рівнями модуля пружності і коефіцієнта водостійкості, при дотриманні вимог до в'язкості технологічної суміші, міцності і зносостійкості композиту.

Ключові слова: компромісна оптимізація, композиційний матеріал, експериментальностатистична модель, рецептурно-технологічне поле, ітераційне випадкове сканування, наповнене карбамідне зв’язуюче.

\title{
МНОГОКРИТЕРИАЛЬНЫЙ ПОИСК РАЦИОНАЛЬНЫХ РЕШЕНИЙ ПРИ РАЗРАБОТКЕ СТРОИТЕЛЬНЫХ КОМПОЗИТОВ
}

\author{
${ }^{1}$ Ляшенко Т.В., д.т.н., профессор, \\ frabul16@gmail.com, ORCID: 0000-0002-6232-4866 \\ ${ }^{1}$ Антонюк Н.P., к.т.н., доцент, \\ antonuk_nr@ukr.net, ORCID: 0000-0003-1730-0723 \\ ${ }_{1}^{1}$ Одесская государственная академия строительства и архитектуры \\ ул. Дидрихсона, 4, г. Одесса, 65029, Украина
}

\begin{abstract}
Аннотация. Констатируется многокритериальность задач при разработке высокоэффективных строительных композитов и необходимость количественных описаний связей характеристик материала, критериев качества, ресурсосбережения и других критериев с факторами состава материала, параметрами процессов производства и условий эксплуатации. Выделяются экспериментально-статистические модели в качестве описаний рецептурно-технологических полей критериев (свойств). Называются используемые подходы к решению задач многокритериальной оптимизации и их недостатки.

Предлагается метод и описывается алгоритм итерационного случайного сканирования рецептурно-технологических полей свойств, который позволяет решать неисчерпаемое многообразие оптимизационных задач. Предназначенный для поиска компромиссного решения при нескольких критериях оптимальности и требованиях спецификаций по ряду критериевограничений, метод позволяет определить и множество допустимых решений, и оптимумы по индивидуальным критериям. Алгоритм достаточно универсален. Не имеет принципиальных ограничений на число оптимизируемых критериев. Легко реализуем в табличном процессоре, в интерактивном режиме. На любой итерации к числу критериев могут быть добавлены требующие минимизации ресурсоемкие факторы, изменены другие условия задачи (по мере получения технологической информации в вычислительном эксперименте). На каждой итерации из множества генерируемых рецептурно- технологических вариантов отбираются те, что удовлетворяют нормативным ограничениям, затем область поиска сжимается при пошаговом приближении к оптимумам критериев оптимальности. Этапы и результаты поиска компромиссного оптимума иллюстрируются на примере разработки карбамидного связующего, наполненного смесью зерен карбида кремния, мелких и крупных зерен андезита. Определен состав, обеспечивающий компромисс между максимальными уровнями модуля упругости и коэффициента водостойкости, при соблюдении требований к вязкости технологической смеси, прочности и износостойкости композита.
\end{abstract}

Ключевые слова: компромиссная оптимизация, композиционный материал, экспериментально-статистическая модель, рецептурно-технологическое поле, итерационное случайное сканирование, наполненное карбамидное связующее.

Стаття надійшла до редакції 21.04.2020

108 Bulletin of Odessa State Academy of Civil Engineering and Architecture, 2020, no. 79, page 99-108 